Prismet vil gjerne markere innsatsen til sentrale (norske) religionspedagoger idet de går av med pensjon. Det vil vi gjøre gjennom korte tekster som presenterer deres faglige bidrag og betydningen av det. Forslag og tekster mottas! I denne utgaven av Prismet skriver Geir Skeie om Sidsel Lied som gikk av som professor våren 2017.

\title{
Sidsel Lied - en kraftfull innsats i norsk religions- didaktisk forskning
}

Av GeIR SKeIE, professor i religionsdidaktikk ved Universitetet i Stavanger og Stockholms universitet. Epost: geir.skeie@uis.no

Sidsel Lied er født i 1948, hun utdannet seg som lærer og arbeidet over 20 år i grunnskolen før hun startet høyere studier og en akademisk karriere på 1990tallet. Denne bakgrunnen ser ut til å ha gitt henne spesielt gode forutsetninger for å komme med et unikt bidrag til norsk religionsdidaktikk. Lied startet som vikar ved Høgskolen i Volda før hun i 1997 begynte i fast stilling ved Høgskolen i Hedmark. Det er først og fremst i tilknytning til lærerutdanningen her at Lied har drevet religionsdidaktisk forskning. Dette har gjort at hun på en måte tilhører flere generasjoner av religionsdidaktikere samtidig, dersom man fors $\emptyset$ ker à bruke en slik inndeling (Skeie, 2017).

Denne tilknytning til lærerutdanning gjør at Lied er typisk for mange av norske professorer i religionsdidaktikk/religionspedagogikk. Fagfeltet er svakt institusjonelt innrammet og ofte uklart eller pragmatisk definert på den måten at forskningsinteresse og problemstillinger forteller mer enn organisatorisk plassering og stillingstittel. Da Sidsel Lied ble professor fra 2009, var det i «Religion, livssyn og etikk (RLE)». Hennes professorkolleger i Norsk Religionspedagogisk Forskerforum (NoReFo) har ulike titler, er plassert i ulike typer institutter eller avdelinger, og de fleste er avhengige av gode samarbeidsrelasjoner til kolleger i andre disipliner og fagfelt. Selv om dette strukturelt sett gjør at fagområdet kan bli sårbart, har mange gjort nettopp som Lied og dyrket slike samarbeidsrelasjoner. Hun har blomstret i et stimulerende miljø ved Mjøsa og samarbeidet mye med kolleger som har vært opptatt av språk, kultur, pedagogikk og religion/ livssyn i det stadig mer mangfoldige Norge.

Både egenskaper som samarbeidsorientering og utadvendt virketrang har nok bidratt sammen med en umiskjennelig faglig kvalitetsorientering når Lied har blitt brukt i noen av de utdanningspolitiske prosesser som har vært knytta til 
religions- og livssynsundervisning i skolen. Særlig på slutten av 1990-tallet og begynnelsen av 2000-tallet var hun med i komiteer både knytta til grunnskolens nye læreplan og den første nasjonale lærerveiledningen i KRL. Det er derfor all grunn til å anta at Lied har preget det KRL-faget som så dagens lys i 1997 og som endret norsk grunnskole og lærerutdanning innenfor dette området for godt. Hun har fulgt utviklingen videre og kommentert og diskutert dette ved flere anledninger. Et gjennomgående trekk ved Lieds engasjement både i læreplanspørsmål og i hennes forskning ellers, har vært en nysgjerrig oppmerksomhet overfor hvordan barn og unge oppfatter situasjonen.

Sett utenfra kan det virke som det er tre dominerende impulser som løper sammen i Lieds religionsdidaktiske virksomhet. Den første er selve forskningsorienteringen, som innebærer at man skal ha et solid grunnlag for det man påstår. Det betyr ikke mangel på engasjement og patos når det gjelder saker man brenner for, men at det skal være mulig å levere et regnskap også. Det ville derfor være en feilslutning å anta at Lieds moralske ethos, for eksempel solidariteten med de barn og unge som finnes i skolen og lærerutdanninga, ikke er kombinert med en grundig gjennomtenking av dilemmaer og kritiske perspektiv. Dette leder til den andre impulsen, som handler om hvordan hun gjennomfører sin forskning. Lied har nemlig vist vilje og evnen til å gå i dybden teoretisk, for å finne fast grunn under føttene, når hun har gjennomført sine empiriske studier. Dermed har hun kunnet operere med begreper som er godt definerte. Dette gjør det mulig for andre forskere å følge hennes fotspor, ikke bare for å gå i dem, men for å ettergå dem, unders $\emptyset$ ke prosessen og resultatene. Den tredje impulsen forestiller jeg meg å være delvis et resultat av de nytestamentlige og andre tekststudier hun drev med i hovedfaget, nemlig en interesse for og tolkning av multimodale tekster produsert av barn og unge.

Stimulert av disse impulsene eller energikildene har Lied gitt oss en omfattende forsknings- og formidlingsproduksjon i løpet av de siste tiårene. I ettertid er det interessant å vende tilbake til hennes bok om elever i møte med bibeltekster (Lied, 1996). Boka var gitt ut på IKO-Forlaget, og tidlig kom det også artikler av henne om elever og bibellesning i Prismet, hvor hun har vært en flittig bidragsyter gjennom årene. Boka kan leses som et tidstypisk uttrykk for den energi og entusiasme overfor arbeid med den kristne kulturarven i skolen som preget mange i tida omkring 1997. Andre problematiserte selve begrepet «kulturarv» i denne sammenheng, fordi det ble oppfattet å privilegere den kristne tradisjonen på en urimelig måte. Når man nærmer seg boka 20 år seinere, kan Lieds tale om «eleven som forsker og kunstner» sies å passe godt inn i den pågående læreplanprosess. I kjølvannet av Ludviksenutvalget kan det se ut til at nettopp det unders $\emptyset$ kende og skapende synet på fag og elev preger arbeidet omkring «kjernelementer». 
Det er ikke så vanskelig å se linjene fra denne starten i elevers arbeid med bibeltekster og Lieds avhandling noen år seinere. Likevel er det gjort et formidabelt arbeid med grunnleggende spørsmål, teori og metode. Dessuten er materialet annerledes. Avhandlingen unders $\emptyset$ kte elever på mellomtrinnet i møte med ulike religioners fortellinger og analyserte dette ved hjelp av teksttolkningsteori. «Fortellingspedaogikk» hadde vært gjenstand for diskusjon flere steder siden 1990-tallet, og Lied markerte sitt perspektiv på dette blant annet $\mathrm{i}$ Religion \& Livssyn 2001 og 2002. Viktigere var imidlertid det bidraget hun gav gjennom et grundig arbeid med elevtekster for å gjøre Michail Bakhtin til en sentral referanse også i religionsdidaktisk forskning. Her bidro hun til å komplisere, men også fornye, den diskurs om dialog som hadde pågått siden NOU 1995:9. Endelig tok hun i bruk Kress og van Leeuwens metodologi for å analysere sammensatte tekster, også det et nybrottsarbeid i religionsdidaktikken. Gjennom dette arbeidet ble det åpnet opp flere dører mellom ulike faglige og fagdidaktiske tradisjoner.

I stor grad benyttet Lied de samme teoretiske perspektiver på et nytt materiale, da hun i kjølvannet av massakren på Utøya og sprengingen av regjeringskvartalet, oppdaget hvordan folk strømmet til sentrale steder i store byer og gav uttrykk for følelser og tanker gjennom å legge ned små tekster, bilder og gjenstander til minne og ettertanke. For henne var dette mer enn bare et interessant materiale, det var viktige hendelser og handlinger som fortjente en respektfull og samtidig unders $\varnothing$ kende oppmerksomhet. Deltaker og tilskuer behøver ikke være uforenlige roller, men man kan veksle mellom dem. Forskeren Lied kastet seg inn i dette med både organisasjonstalent og analytisk teft. Hun var sentral i det første forskningsmessige arbeidet med materialet og deltok lenge i oppfølgingen av dette. Hadde hun fătt penger til det forskningsprosjekt hun søkte om den gang, ville formodentlig unders $\emptyset$ kelser av minnematerialet, konteksten, og religiøse og livssynsmessige dimensjoner være kommet mye langer enn det er i dag, men mye av det som fortsatt skjer, er takket være den tidlige innsatsen til Lied.

Selv tok hun tematikken inn i det religionsdidaktiske arbeidet gjennom samarbeid med lærerstudenter og lærere, som også gav vitenskapelige tekster som resultat. Dette var arbeidsformer hun hadde erfaring med fra tidligere, og noen av resultatene finnes i flere artikler i Prismet 3/2016.

Indirekte har jeg allerede vært inne på at Lieds profil som religionsdidaktisk forsker har vært preget av bredt samarbeid med andre forskere, med kolleger fra andre fag og med lærerstudenter og lærere. Det viser at religionsdidaktikken som forskningsfelt er avhengig av å søke ut over sin indre krets for å utvikle seg. I tillegg må vi samarbeide med hverandre. Lied har bidratt avgjørende til at vi har et nasjonalt religionsdidaktisk forum i Norge, og hun har over mange år hatt 
et tett samarbeid med svenske religionsdidaktikere som har satt tydelige spor $\mathrm{i}$ nabolandet. Hun har vært gjesteprofessor ved Karlstad universitet gjennom flere år og har bidratt i viktige publikasjoner der (Osbeck \& Lied, 2012).

\section{Referanser}

Lied, S. (1996). Jeg fant, jeg fant - en bibeltekst! Eleven som forsker og kunstner. Oslo: IKOForlaget.

Osbeck, C., \& Lied, S. (2012). Religionsdidaktisk arbeid pågår! Religionsdidaktikk i Hamar og Karlstad. Vallset: Oplanske bokforlag.

Skeie, G. (2017). Where is Norwegian religious education research heading? A discussion based on two dissertations. Nordidactica: Journal of Humanities and Social Science Education (2017:1), 27-48. 